\author{
Sección Médica / Medical
}

Artículos de investigación / Research paper

\title{
First record of phoretic and parasitc mites (Arachnida: Acari) associated with necrophagous flies in Brazil
}

\author{
Primer registro de ácaros (Arachnida: Acari) foréticos y parásitos asociados con moscas necrófagas en Brasil
}

\author{
TAYRA PEREIRA SATO ${ }^{1,2}$, REBECCA LEAL CAETANO ${ }^{3,4}$, CESAR CARRIÇO $^{3,5}$, ADEMAR FERREIRA DA SILVA $^{1}$, \\ GILBERTO SALLES GAZETA ${ }^{1}$ and ZENEIDA TEIXEIRA PINTO ${ }^{3}$
}

\begin{abstract}
Many arthropod species, mainly flies (Diptera) and their phoretic mites are attracted by carrion. This is the first record of phoretic and parasitic mites Leptus sp., Macrocheles muscaedomesticae and Longoseius brachypoda associated with necrophagous flies in Brazil.
\end{abstract}

Key words: Phoresis, Calliphoridae, Muscidae, forensic acarology.

Resumen: Muchas especies de artrópodos principalmente moscas (Diptera) y sus ácaros foréticos son atraídos por la carroña. Este es el primer registro de ácaros foréticos y parásitos Leptus sp., Macrocheles muscaedomesticae y Longoseius brachypoda, en moscas necrófagas en Brasil.

Palabras clave: Foresia, Calliphoridae, Muscidae, acarología forense.

\section{Introduction}

The transportation of one animal by another is known as phoresy (Walter and Proctor 1999). Phoresy is a survival strategy for maintaining species that can act as predators or parasites in different development stages (Rodrigueiro and Prado 2004). According to Rodrigueiro and Prado (2004), Kaliszewski et al. (1995), Athias-Binche (1984), AthiasBinche and Morand (1993), Binns (1982) y Farish and Axtell (1971) in this phenomenon of transportation to other habitats, the phoretic stage or phoront seeks and attaches the surface of another animal, then enters quiescence or feeding state. The relation between carrier and phoretic specimens is transitory; it usually ends when the host reaches a new area or carcass, and the phoretic detaches from its body (Walter and Proctor 1999; Perotti and Braig 2009).

Arthropod fauna associated with carcasses are diverse, mainly compounded by flies (Diptera) and beetles (Coleoptera); which are the major groups of forensic importance (Mise et al. 2007; Miranda and Bermúdez 2008).

Flies are the very first to reach the carrion, laying eggs almost immediately (Erzinçlioglu 1985; Smith 1986; Greenberg 1991; Carvalho et al. 2000). However, flies do not come alone; some of them will get to carrion with lots of phoretic mites attached to them (Perotti et al. 2009). Phoretic mites are the most abundant arthropods found on carcasses and corpses (Mégnin 1894; Goff 1991); usually transported by scavenger specimen (Perotti and Braig 2009).
Mites can provide valuable information about the time of colonization of carcasses (Perotti and Braig 2009). The presence of a specific phoretic on carrion can confirm the presence of its specific carrier at some point in time, even when the carrier is no longer present (Perotti and Braig 2009). Mites associated with flies have been the subject of some researchers, such as Fain and Greenwood (1991) who studied scuttle flies (Phoridae) carrying mites Macrocheles disneyi Fain and Greenwood, 1991 attached to the body to start a new succession of mite; Bermúdez and Pachar (2010) reported mites larvae of Leptus sp. in association with flies from human corpses in Panama, collected in field work and in autopsies and Pinto et al. (2014) reported for the first time the presence of Leptus sp. associated with sarcophagid fly in Brazil.

Mite fauna is usually overlooked, due to their size, to the absence of specific knowledge about them or to the incorrect use of forensic methods (Perotti et al. 2009). In this study the phoretic mite associated with necrophagous flies is reported in Mato Grosso do Sul State, Brazil.

\section{Material and methods}

Fly species were obtained from four traps made with plastic bottles (Cunha and Lomônaco 1996), with carrion of Sardinella brasiliensis (Steindachner, 1879) separated by $100 \mathrm{~m}$ from each other and placed at $1.5 \mathrm{~m}$ of the ground. The collections were performed daily, during one week in February 2015, in a Cerrado area at the Hiroo Onoda Farm, in

\footnotetext{
${ }^{1}$ M. Sc., B. Sc., Ph. D.; Instituto Oswaldo Cruz/Fundação Oswaldo Cruz (IOC/FIOCRUZ), Laboratório de Referência Nacional em Vetores das Riquetsioses (LIRN), Avenida Brasil, 4365. CEP 21040-900. Rio de Janeiro, RJ, Brazil. http://www.ioc.fiocruz.br. ${ }^{2}$ M. Sc. Universidade Federal de Juíz de Fora (UFJF). Postgraduate Program in Behavior and Animal Biology, Juiz de Fora, MG, Brazil. http://www.ufjf.br/ufjf/. ${ }^{3}$ Ph. D. Instituto Oswaldo Cruz/Fundação Oswaldo Cruz (IOC/FIOCRUZ), Laboratório de Educação em Ambiente e Saúde, Avenida Brasil, 4365. CEP 21040-900, Rio de Janeiro, RJ, Brazil. http://www.ioc. fiocruz.br, zeneida@ioc.fiocruz.br. ${ }^{4}$ Ph. D. Universidade Estácio de Sá - UNESA, Rua Bingen, 50. CEP 25660-004, Petrópolis, RJ, Brazil. ${ }^{5}$ Ph. D. Instituto Brasileiro de Medicina de Reabilitação-IBMR/LAUREATE- Av. das Américas, 2603 CEP 22631-002, Rio de Janeiro, RJ, Brazil. Corresponding author: Ph. D. Zeneida Teixeira Pinto. Instituto Oswaldo Cruz/Fundação Oswaldo Cruz (IOC/FIOCRUZ), Laboratório de Educação em Ambiente e Saúde, Avenida Brasil, 4365. CEP 21040-900, Rio de Janeiro, RJ, Brazil, http://www.ioc.fiocruz.br, zeneida@ioc.fiocruz.br.
} 


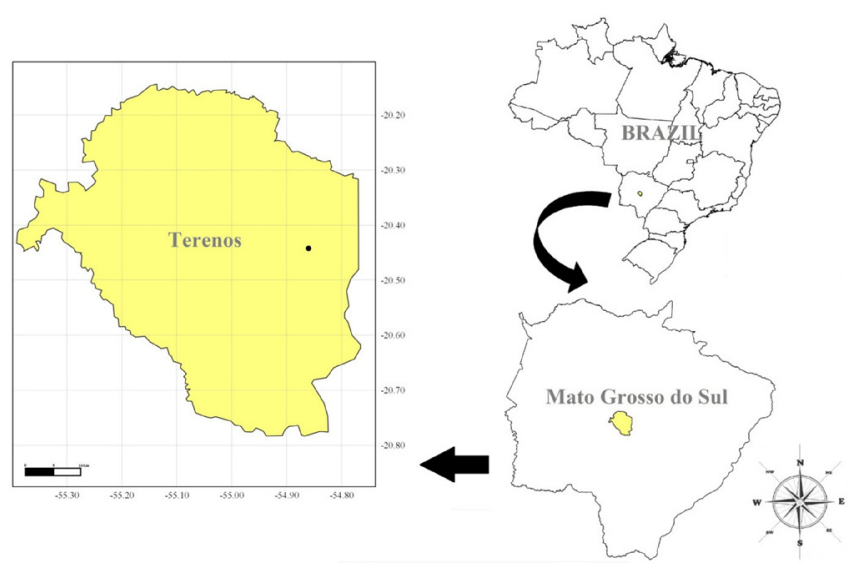

Figure 1. Map indicating the collection site of phoretic mites associated with necrophagous flies in Terenos city, Mato Grosso do Sul State, Brazil.

Terenos city, Mato Grosso do Sul State, Brazil (20²6’32"S and 54 $51^{\prime} 37^{\prime \prime} W$ ) (Fig. 1).

Flies were identified by using dichotomic keys from Carvalho et al. (2002) and Mello (2003) and checked out for the presence of mites. The specimens were deposited at Laboratório de Educação em Ambiente e Saúde (LEAS), Instituto Oswaldo Cruz, Fundação Oswaldo Cruz (IOC/ FIOCRUZ).

Mites were mounted between slide and coverslip in Hoyer's mounting media as preservative (Flechtmann 1973) and examined under light microscopy. Each specimen was properly identified at genus or species level following Flechtmann (1975), and Krantz and Walter (2009).

Mites were deposited at the collection of Laboratório de Referência Nacional em vetores das Riquetsioses (LIRN), Instituto Oswaldo Cruz, Fundação Oswaldo Cruz (IOC/ FIOCRUZ), 10.i i. 2015, leg. T. P. Sato (Table 1).

\section{Results}

In the present study 123 necrophagous flies (Chrysomya albiceps (Wiedmann, 1819), Chrysomya putoria (Wiedmann, 1830), Chrysomya megacephala (Fabricius, 1794), Ophyra aenescens (Wiedman, 1830), Ophyra chalcogaster (Wiedmann, 1824) and Peckia chrysostoma (Wiedmann, 1830), were collected, of which only six from 31 specimens of $C$. albiceps and one from three specimens of $O$. aenescens were recorded carrying mites. Acari species belong to three distinct families: Erythraeidae, Macrochelidae and Digamasellidae (Table 1).

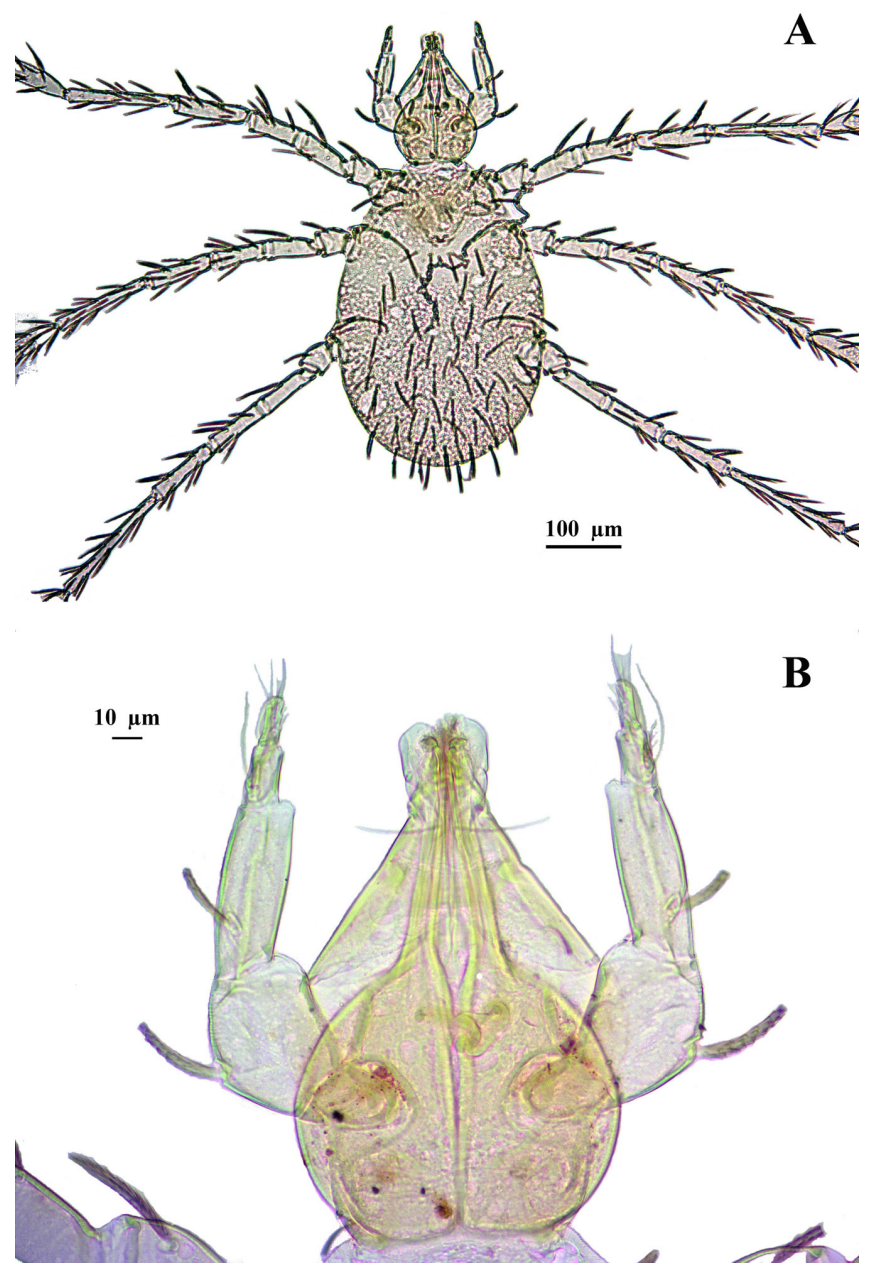

Figure 2. Leptus sp. (Acari: Erythraeidae) collected from necrophagous fly Chrysomya albiceps (Diptera: Calliphoridae) in Terenos city, Mato Grosso do Sul State, Brazil. A. Idiosoma dorsal view. B. Gnathosoma dorsal view.

Specimens of genus Leptus sp. (Erythraeidae) and Macrocheles muscadomesticae (Scopoli, 1772) (Macrochelidae) (Figs. 2 and 3) were found in different body regions of the calliphorid $C$. albiceps. The first one was found attached to legs and eyes, and the second one was found attached to abdomen of blowflies (Table 1).

One specimen of Longoseius brachypoda Hurlbutt, 1967 (Digamasellidae) (Fig. 4) was found stuck in a set in the portion of the abdomen of the muscid $O$. aenescens (Table 1).

Table 1. Site of attach of phoretic mites on necrophagous flies in Mato Grosso do Sul State, Brazil.

\begin{tabular}{|c|c|c|c|c|}
\hline Family & Species & Number voucher & Site of attach & Hosts \\
\hline \multirow{5}{*}{ Erythaeidae } & Leptus sp. & CAVAISC-ACA-1787 & Between legs I and II & Chrysomya albiceps \\
\hline & Leptus sp. & CAVAISC-ACA-1787 & Between legs II and III & Chrysomya albiceps \\
\hline & Leptus sp. & CAVAISC-ACA-1787 & Behind eyes & Chrysomya albiceps \\
\hline & Leptus sp. & CAVAISC-ACA-1787 & Between legs I and II & Chrysomya albiceps \\
\hline & Leptus sp. & CAVAISC-ACA-1787 & Between legs II and III & Chrysomya albiceps \\
\hline Macrochelidae & Macrocheles muscadomesticae (Scopoli, 1772) & CAVAISC-ACA-1788 & Abdomen & Chrysomya albiceps \\
\hline Digamasellidae & Longoseius brachypoda Hurlbutt, 1967 & CAVAISC-ACA-1789 & Abdomen & Ophyra aenescens \\
\hline
\end{tabular}




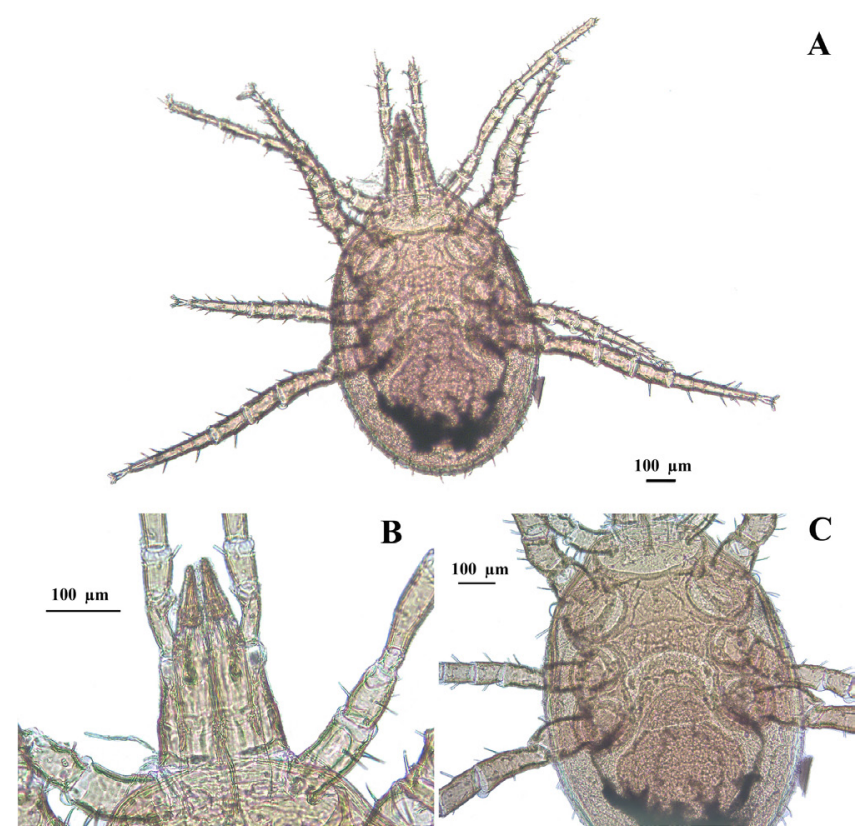

Figure 3. Macrocheles muscadomesticae (Acari: Macrochelidae) collected from necrophagous fly Chrysomya albiceps (Diptera: Calliphoridae) in Terenos city, Mato Grosso do Sul State, Brazil. A. Idiosoma dorsal view. B. Gnathosoma dorsal view. C. Idiosoma ventral view.

\section{Discussion}

The cosmopolitan Leptus Latreille, 1796 is a genus of mites in Erythraeidae family. Larvae of this family are typically parasites on other arthropods and vertebrates, whereas nymphs and adults are free predators (Southcott 1992; Haitlinger 2000; McAloon and Durden 2000; Krantz and Walter 2009). The genus comprises more than 80 species widespread the world (Haitlinger 2006).

This research presents for the first time the parasitic association between Leptus sp. and C. albiceps in Brazil. For this country the occurrence of this mite genus was observed by Haitlinger (2004) associated with plants in Foz do Iguaçu and Rio de Janeiro; Morais et al. (2007) associated with Citrus deliciosa var. Montenegrina in Rio Grande do Sul; Teixeira (2011) with honey bees in Sao Paulo; Pereira et al. (2012) with Heteroptera specimens in Minas Gerais, and Pinto et al. (2014) associated with the sarcophagid fly Tricharaea (Sarothromyia) femoralis (Schiner, 1868) in Rio de Janeiro.

Species from Macrochelidae family are cosmopolitan and predatory, many of which occupying specialized and often unstable habitats, such as degraded soil, organic matter in decomposition and decaying flesh (Flechtmann 1975). Most of them have adapted to life in /dung where potential for rapid growth population exists due to prey availability (Krantz 1998; Krantz and Walter 2009).

This is the first time that the phoretic association between $M$. muscaedomesticae and $C$. albiceps in Brazil was observed. Specimens of $M$. muscaedomesticae make obligatory phoresy, which means that the specimen cannot develop to adult or reproductive stage without phoretic transport (Amendt et al. 2010). According to Athias-Binche (1984), the species appears to be specialized with muscoid flies, and it is believed that there is, simultaneously, an interaction of phoresy and a predation relation, feeding on the eggs and the newly hatched larvae of Muscidae (Flechtmann

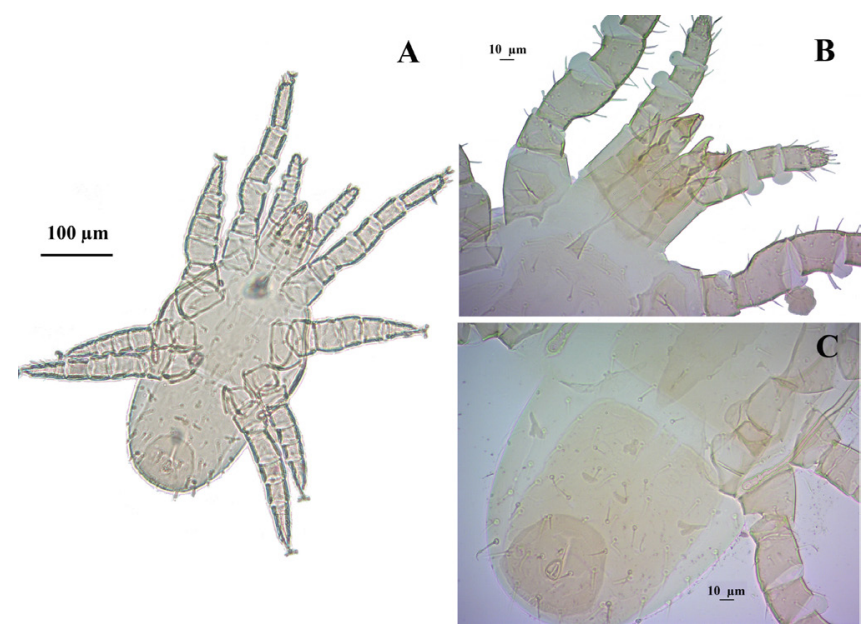

Figure 4. Longoseius brachypoda (Acari: Digamasellidae) collected from necrophagous fly Ophyra aenescens (Diptera: Muscidae) in Terenos city, Mato Grosso do Sul State, Brazil. A. Idiosoma ventral view. B. Gnathosoma dorsal view. C. Idiosoma ventral view.

1975). Commonly, this interaction occurs with Muscidae or Fanniidae (Perotti and Brasesco 1997). This species has been associated with Musca domestica Linnaeus, 1758 by various workers (Filipponi 1955). In addition to the housefly, the mite is phoretic on Eristalis tenax Linnaeus, 1758, as well as on certain beetles and rodents (Bregetova and Koroleva 1960). Marchiori et al. (2000) also reported the occurrence of this mite in Chrysomelidae in South of Goiás, Brazil.

The Digamasellidae includes predaceous mites commonly found in litter, soil and decaying organic being. Longoseius Chant, 1961 the most representative genus. They are generally found beneath bark in association with wood boring beetles (Chant 1961). Nematodes, arthropod eggs, early stages of insects or mites, springtails, and possibly fungi constitute the known prey of these mites (Walter et al. 1988; Krantz and Walter 2009).

This is the first record of L. brachypoda playing phoresy in the muscid $O$. aenescens in the state of Mato Grosso do Sul as well as throughout Brazil. This genus has been previously reported in phoretic association with wood boring beetles (Cerambycidae, Elateridae and Pyrochroidae) found in deutonymph stage under the elytra of beetles (Womersley 1954; Chant 1961; Kinn 1984).

\section{Acknowledgements}

We are very thankful to The Mycological Collection Trichocomaceae (FIOCRUZ - IOC), facilitated the use of microscopically image capture (Mário Gatti and Rodolfo Armando da Cunha) and to Paulo Vander Ferreira Santana for his help with the article English revision. We would also like to thank Renan Olivier for providing the map. We would like to thank the Conselho Nacional de Desenvolvimento Científico e Tecnológico (CNPq), Coordenação de Aperfeiçoamento de Pessoal de Nível Superior (CAPES) and Fundação Oswaldo Cruz for the grants and fellowships.

\section{Literature cited}

AMENDT, J.; CAMPOBASSO, C. P.; GOFF, M. L.; GRASSBERGER, M. 2010. Current concept in forensic entomology. Springer. 379 p. 
ATHIAS-BINCHE, F. 1984 La phorésie chez les acariens uropodides (Anactinotriches), une stratégie écologique originale. Acta Oecologica 5: 119-133.

ATHIAS-BINCHE, F.; MORAND, S. 1993. From phoresy to parasitism: the example of mites and nematodes. Research and Reviews in Parasitology 53: 73-79.

BERMÚDEZ, S.; PACHAR, J. V. 2010. Artrópodos asociados a cadáveres humanos en Ciudad de Panamá, Panamá. Revista Colombiana de Entomologia 36 (1): 86-89.

BINNS, E. S. 1982. Phoresy as migration: some functions and aspects of phoresy in mites. Biological Review, Mainz 57: 571620.

BREGETOVA, N. G.; KOROLEVA, E. V. 1960. Mites of the family Macrochelidae Vitchern 1930 in the fauna of U.S.S.R. Parasitology 56: 132-154.

CARVALHO, L. M. L.; THYSSEN, P. J.; LINHARES, A. X.; PALHARES, F. A. B. 2000. A Checklist of arthropods associated with pig carrion and human corpses in Southeastern Brazil. Memórias do Instituto Oswaldo Cruz 95 (1): 135-138.

CARVALHO, C. J. B.; MOURA, M. O.; RIBEIRO, P. B. 2002. Chave para adultos de dípteros (Muscidade, Fanniidae e Anthomyidae) associados ao ambiente humano no Brasil. Revista Brasileira Entomologia 46 (2): 107-114.

CHANT, D. A. 1961. A new genus and species of mite in the family Digamasellidae Evans (Acarina). Acarology 3: 11-13.

CUNHA, C. L.; LOMÔNACO, C. 1996. Monitorização de impacto ambiental provocado por dispersão de moscas em bairros adjacentes a uma granja avícola. Sociedade Entomológica do Brasil 25: 1-12.

ERZINÇLIOGLU, Z. 1985. Few flies on forensic entomologists. New Scientist. $15 \mathrm{p}$

FAIN, A.; GREENWOOD, M. T. 1991. Notes on a small collection of mites Acari phoretic on Diptera mainly Phoridae from the British Isles. Bulletin de 1'Institut Royal des Science Naturelles de Belgique Entomologie 61: 193-197.

FARISH, D. J.; AXTELL, R. C. 1971. Phoresy redefined and examined in Macrocheles muscaedomesticae (Acarina: Macrochelidae). Acarologia 13: 16-25.

FILIPPONI, A. 1955. Sulla natura dell'associazione tra Macrocheles muscadomesticae e Musca domestica. Rivista di Parassitologia 16 (2): 83-102.

FLECHTMANN, C. H. W. 1973. Ácaros de importância médicoveterinária. Vol. 16. NBL Editora. 192 p.

FLECHTMANN, C. H. W. 1975. Elementos de Acaralogia. São Paulo, Livraria Nobel S. A. 344 p.

GOFF, M. L. 1991. Comparison of insect species associated with decomposing remains recovered inside dwellings and outdoors on the island of Oahu, Hawaii. Journal Forensic Science 36 (3): 748-753.

GREENBERG, B. 1991. Flies as forensic indicators. Journal of Medical Entomology 28 (5): 565-577.

HAITLINGER, R. 2000. Four new species of Leptus Latreille, 1796 (Acari, Prostigmata, Erythraeidae) from Peru. Bolletino del Museo Regionale Scienze Nataturali 17 (1): 149-162.

HAITLINGER, R. 2004. Three new species of Leptus Latreille, 1796 and the first record of Leptus onnae Haitlinger, 2000 (Acari: Prostigmata: Erythraeidae) from Brazil. Systematic \& Applied Acarology 9: 147-156.

HAITLINGER, R. 2006. Dasitrombium margeritanum sp. n., Leptus tiranicus $\mathrm{sp} . \mathrm{n}$. and the first record of $L$. olafi Haitlinger (Acari: Prostigmata: Erythraeidae) ectoparasitic on Orthoptera and Diptera (Insecta) from Margerita, Venezuela. Polish Journal of Entomology 75: 347-357.

KALISZEWSKI, M.; ATHIAS-BINCHE, F.; LINDQUIST, E. E. 1995. Parasitism and parasitoidism in Tarsonemina (Acari: Heterostigmata) and evolutionary considerations. Advances in Parasitology 35: 335-367.

KINN, D. N. 1984. Life cycle of Dendrolaelaps neodisetus (Mesostigmata: Digamasellidae), a nematophagous mite associated with pine bark beetles (Coleoptera: Scolytidae). Environmental Entomology 13 (4): 1141-1144.

KRANTZ, G. W. 1998. Specialization and systematics in acarology: reflections and predictions. pp. 1-4. In: Mitchell, R.; Horn, D. J.; Needham, G. R.; Welbourn, W. C. (Eds.). Acarology IX: Volume I, Proceedings (Ohio Biological Survey: Columbus).

KRANTZ, G. W.; WALTER, D. E. 2009. A manual of Acarology. Texas Tech University Press, USA, 816 .

MARCHIORI, C. H.; SILVA, C. G.; CALDAS, E. R.; VIEIRA, C. I. S.; ALMEIDA, K. G. S.; TEIXEIRA, F. F.; LINHARES, A. X. 2000. Artrópodos associados com carcaça de suíno em Itumbiara, Sul de Goiás. Arquivos do Instituto Biológico 67: $167-170$

McALOON, F. M.; DURDEN, L. A. 2000. Attachment sites and frequency distribution of erythraeid mites, Leptus indianensis (Acari: Prostigmata), ectoparasitic on harvestmen Leiobunum formosum (Opiliones). Experimental and Applied Acarology 24: 561-567.

MÉGNIN, J. 1894. La faune des cadavres: application de l'entomologie a la médecine légale. Encyclopédie Scientifique des Aides Mémoires. Masson et Gauthiers-Villars, Paris. 214 p.

MELLO, R. P. 2003. Chave para identificação das formas adultas das espécies da família Calliphoridae (Diptera, Brachycera, Cyclorrhapha) encontradas no Brasil. Entomologia Veterinária 10 (2): 255-268.

MIRANDA, R.; BERMÚDEZ, S. 2008. Ácaros (Arachnida: Acari) asociados con moscas Calliphoridae (Diptera: Oestroidea) en tres localidades de Panamá. Revista Colombiana Entomologia 34 (2): 192-196.

MISE, K. M.; ALMEIDA, L. M.; MOURA, M. O. 2007. Levantamento da fauna de Coleoptera que habita a carcaça de Sus scrofa L., em Curitiba, Paraná. Revista Brasileira de Entomologia 51 (3): 358-368.

MORAIS, R. M.; OTT, R.; OTT, A. P.; REDAELLI, L. R. 2007. Aranhas e ácaros predadores em copas de tangerineiras montenegrina, mantidas sob manejo orgânico, em Montenegro, R. S. Neotropical Entomology 36 (6): 939-948.

PEREIRA, A. I. A.; FADINI, M. A. M.; PIKART, T. G.; ZANUNCIO J. C.; SERRÃO, J. E. 2012. New hosts and parasitism notes for the mite Leptus (Acari: Erythraeidae) in fragments of the Atlantic Forest, Brazil. Brazilian Journal of Biology 72 (3): 611616.

PEROTTI, M. A.; BRAIG, H. R. 2009. Phoretic mites associated with animal and human decomposition. Experimental and Applied Acarology 49: 85-124.

PEROTTI, M. A.; BRASESCO, M. J. A. 1997. Orientación química de Macrocheles muscaedomesticae Scopoli (Acari: Macrochelidae) y percepción a distancia de posturas de Musca domestica (Diptera: Muscidae) y Calliphora vicina (Diptera: Calliphoridae). Revista de la Sociedad Entomológica Argentina 56: 67-70.

PEROTTI, M. A.; BRAIG, H. R.; GOFF, M. L. 2009. Phoretic mites and carcasses: acari transported by organisms associated with animal and human decomposition. pp. 69-92. In: Amendt, J.; Goff, M. L.; Campobasso, C. P.; Grassberger, M. (Eds.). Current concept in forensic entomology. Springer, Dordrecht, Netherlands.

PINTO, Z. T.; CARRIÇO, C.; CAETANO, R. L.; BARBOSA, R. R.; MENDONÇA, P. M.; QUEIROZ, M. M. C. 2014. Fist record of Leptus sp. Latreille, 1796 (Acari: Erythraidae) from Itaipuaçu beach, Maricá, RJ, Brazil. Check List 10 (4): 954-956.

RODRIGUEIRO, T. S. C; DO PRADO, A. P. 2004. Macrocheles muscadomesticae (Acari: Macrochelidae) and a species of Uroseius (Acari: Polyaspididae) phoretic on Musca domestica (Diptera: Muscidae): effects on dispersal and colonization of poultry manure. Iheringia, Série Zoollogia, Porto Alegre 94 (2): 181-185.

SMITH, K. G. V. 1986. A manual of forensic entomology. Cornell University Press, New York. 205 p. 
SOUTHCOTT, R. V. 1992. Revision of the larvae of Leptus Latreille (Acarina: Erythraeidae) of Europe and North America, with descriptions of post-larval instars. Zoological Journal of the Linnen Society 105: 1-153.

TEIXEIRA, E. W. 2011. Larvas de Leptus sp. Latreille 1796 (Acarina: Erythraeidae) em abelhas africanizadas A. mellifera Linnaeus 1758 (Hymenoptera: Apidae), no Brasil. Pesquisa Tecnológica 8: 27.

WALTER, D. E.; PROCTOR, H. 1999. Mites. Ecology, evolution and behavior. Everbest Print. Hong Kong. 321 p.

WALTER, D. E.; HUNT, H. W.; ELLIOTT, E. T. 1988. Guilds or functional groups? An analysis of predatory arthropods from a shortgrass steppe soil. Pedobiologia 31: 247-260.

WOMERSLEY, H. 1954. Two new species of mites (Acarina: Mesostigmata: Ascidae) associated with bark-boring beetles from South Australia. Records of the South Australian Museum 11: 113-116.

Received: 3-May-2016 • Accepted: 1-Oct-2017

Suggested citation:

SATO, T. P.; CAETANO, R. L.; CARRIÇO, C.; SILVA, A. F. da; GAZETA, G. S.; PINTO, Z. T. 2018. First record of phoretic and parasitc mites (Arachnida: Acari) associated with necrophagous flies in Brazil. Revista Colombiana de Entomología 44 (1): 48 52. Enero - Junio 2018. 